\title{
JOINT VENTURES IN THE CANADIAN ENERGY INDUSTRY
}

\author{
BRAD GRANT*
}

This article explores the concept of a joint venture and the use of joint venture agreements in the Canadian energy industry. The discussion is particularly timely as there have been a number of significant joint ventures in the Canadian energy industry, particularly with respect to Asia Pacific investors who have spent billions of dollars to lock up parts of Canada's oil and gas reserves. With a growing demand for energy among Asia Pacific countries, the article suggests that joint ventures will continue to be significant in the development of Canada's energy industry. This article provides an overview of the different forms of joint ventures (the corporation, partnership, and contractual joint venture) and the risks and benefits associated with each. This article also addresses some of the key issues with respect to joint ventures generally.
Cet article explore le concept de coentreprise et le recours à des ententes de coentreprises dans le secteur énergétique canadien. La discussion est particulièrement pertinente étant donné qu'il y a plusieurs coentreprises importantes dans le secteur énergétique au pays, surtout en ce qui concerne les investisseurs de l'Asie du Pacifique ayant dépensé des milliards de dollars pour s'assurer une partie de réserves gazières et pétrolières au Canada. Compte tenu de la demande croissante de l'énergie dans les pays de l'Asie du Pacifique, cet article fait penser que les coentreprises demeureront importantes dans le secteur énergétique canadien. Cet article donne un aperçu de plusieurs formes de coentreprises (corporation, partenariat et coentreprise contractuelle) ainsi que des risques et des avantages associés à chacune. L'article aborde aussi quelques questions clés générales des coentreprises.

\section{TABLE OF CONTENTS}

I. The Concept of A Joint Venture $\ldots \ldots \ldots \ldots \ldots \ldots \ldots \ldots \ldots . \ldots . \ldots . \ldots 374$

II. USE OF THE JOINT VENTURE IN THE CANADIAN ENERGY INDUSTRY $\ldots . .375$

III. RATIONALE FOR FORMING JOINT VENTURES $\ldots \ldots \ldots \ldots \ldots \ldots \ldots . \ldots . \ldots$

IV. FormS OF JOINT VENTURES . . . . . . . . . . . . . . . . . . . 378

A. Joint VentuRE CoRPoRATION . . . . . . . . . . . . . . . 379

B. Joint Venture PARTNERShip . . . . . . . . . . . . . . . 380

C. Contractual Joint Venture $\ldots \ldots \ldots \ldots \ldots \ldots \ldots \ldots \ldots . \ldots \ldots$

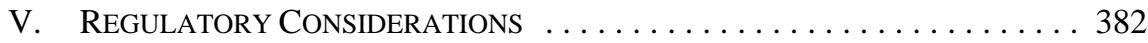

VI. Joint VeNTURE DocumENTATION $\ldots \ldots \ldots \ldots \ldots \ldots \ldots \ldots \ldots . \ldots \ldots$

VII. KEY COMMERCIAL CONSIDERATIONS $\ldots \ldots \ldots \ldots \ldots \ldots \ldots \ldots . \ldots \ldots 6$

A. SCOPE Of THE Joint Venture $\ldots \ldots \ldots \ldots \ldots \ldots \ldots \ldots$

B. Governance of the Joint Venture $\ldots \ldots \ldots \ldots \ldots \ldots \ldots . \ldots . \ldots 387$

C. Contributions And FinANCING $\ldots \ldots \ldots \ldots \ldots \ldots \ldots \ldots . \ldots \ldots$

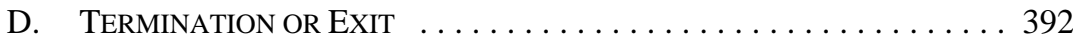

E. CONFIDENTIALITY AND INTELLECTUAL PROPERTY $\ldots \ldots \ldots \ldots 393$

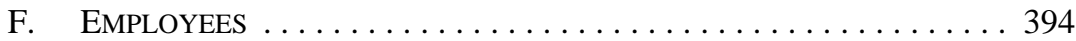

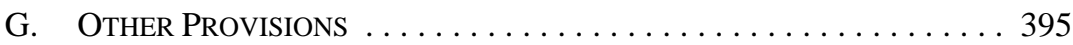

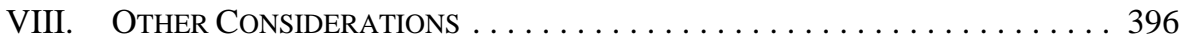

Partner, Stikeman Elliott LLP, Calgary, Alberta, with thanks to Erica Pridham, Susan Hutton, Doug Richardson, Gary Clarke, Glenn Cameron, John Cuthbertson, and Tim Kitchen for their valuable assistance. 
IX. Concluding Thoughts . . . . . . . . . . . . . . . . . 397

APPENDIX A: SUMMARY OF RECENT CANADIAN

ENERGY JOINT VENTURES . . . . . . . . . . . . . . . . . . . . . . . . . . . . . . 398

\section{The CONCEPT OF A JoINT Venture}

Joint ventures have been commonly used in a number of industries, including the energy industry. However, the concept of a joint venture is often elusive, as the term "joint venture" is used in a wide array of relationships of varying size and significance and has a variety of different structures. Joint ventures can range from "short-term, loose contractual alliances

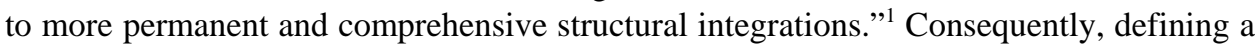
joint venture is more of an art than a science. ${ }^{2}$

While there is no precise meaning of a joint venture in law, ${ }^{3}$ a joint venture has been defined as "[a] business undertaking by two or more persons engaged in a single defined project. The necessary elements are: (1) an express or implied agreement; (2) a common purpose that the group intends to carry out; (3) shared profits and losses; and (4) each member's equal voice in controlling the project." ${ }^{4}$ Canadian courts have stated that a joint venture "contemplates an enterprise jointly undertaken, that it is an association of such joint undertakers to carry out a single project for profit; that the profits are to be shared, as well as the losses, though the liability of a joint adventurer for a proportionate part of the losses or expenditures of the joint enterprise may be affected by the terms of the contract." ${ }^{\prime 5}$ These descriptions indicate that a joint venture arises by way of contract and involves a shared purpose and a sharing of the economic benefits arising therefrom.

Within Canada, the definition of joint venture often overlaps with the concept of a partnership. The Partnership Act ${ }^{6}$ defines a partnership as the relationship of "persons carrying on a business in common with a view to profit." Given the definitions of joint venture discussed above, the relationship among joint venturers is similar to the relationship among partners under the Partnership Act. Since there is not a well-developed understanding of a joint venture relative to a partnership, there is often uncertainty among joint venturers as to whether or not their specific joint venture will be determined to be a partnership. This uncertainty is obviously not desirable. This has prompted a review by the Alberta Law Reform Institute (ALRI) in which consideration is given to allowing parties to opt out of the Partnership Act and the common law of partnership, to be left to be governed by the law of contract, and the implications of doing so. ${ }^{7}$

\footnotetext{
1 “Joint Ventures in Canada,” Mondaq Business Briefing (16 October 2006), online: Highbeam Business <http://business.highbeam.com/165602/article-1G1-153419228/joint-ventures-canada>.

See e.g. LIUNA, Local $183 v$ Res-Can Joint Venture, [1999] OLRB Rep 1087 at para 8.

Ben 102 Enterprises Ltd v Ben 105 Enterprises Ltd, 2007 BCSC 1069, 37 BLR (4th) 52 at para 101. Black's Law Dictionary, 8th ed, sub verbo “joint venture.”

Central Mortgage \& Housing Corp v Graham (1973), 43 DLR (3d) 686 at 705 (NSSC (TD)) [Central Mortgage], citing Samuel Williston, A Treatise on the Law of Contracts, 3d ed by Walter HE Jaeger (Mount Kisco, NY: Baker, Voorhuis \& Co, 1959) vol 2 at 554.

Partnership Act, RSA 2000, c P-3, s 1(g).

ALRI, Joint Ventures (Edmonton: ALRI, 2011), online: ALRI <http://www.law.ualberta.ca/alri/docs/
} cm014.pdf $>$. 
While there is some imprecision in the concept of joint ventures in North America, the concept of a joint venture is often even more uncertain in other parts of the world. In European law, there is no precise meaning of joint venture and the concept is better defined under the rules of company law. ${ }^{8}$ Similarly, in many Asian countries there is no common use of the joint venture concept. This is important to remember for North American entities when dealing with foreign entities in establishing joint ventures, as there may be some skepticism and uncertainty with the use of joint ventures by foreign entities.

As the foregoing discussion indicates, joint ventures can be quite different and varied. That is part of the difficulty in accurately defining a joint venture. A joint venture can be used for a specific project that may only last weeks or months, or for a continuing business relationship that may continue for decades. The purpose behind, and time horizon of, the joint venture may have profound impacts on how a joint venture is structured.

\section{USE OF THE JOINT VENTURE IN THE CANADIAN ENERGY INDUSTRY}

Despite the potential for confusion around joint ventures as a legal concept, joint ventures have a long history of use in the energy industry in Canada. Joint ventures are commonly used with respect to the exploration and development of petroleum and natural gas leases and there is a well-defined understanding of relationships with respect to these types of joint ventures. Likewise, midstream arrangements, including pipelines, facilities, and storage, have often been in the form of joint ventures. Joint ventures are also commonly used in the power sector, both for large projects, such as nuclear power facilities, or smaller renewable energy projects, such as those for solar and wind.

Joint ventures have also been present for a long time in the development of some of Canada's most significant oil and gas resources. In the Alberta oil sands, Syncrude Canada Ltd. operates its oil sands projects as a joint venture comprised of Canadian Oil Sands Partnership \#1, Imperial Oil Resources, Mocal Energy Limited, Murphy Oil Company Ltd., Nexen Oil Sands Partnership, Sinopec Oil Sands Partnership, and Suncor Energy Oil and Gas Partnership. ${ }^{9}$ Likewise, the Athabasca Oil Sands Project is a joint venture involving Shell Canada Energy, Chevron Canada Limited, and Marathon Oil Canada Corporation. ${ }^{10}$ Hibernia Management and Development Company Ltd. is a joint venture by ExxonMobil Canada Ltd., Chevron Canada Resources, Suncor Energy, Canada Hibernia Holding Corporation, Murphy Oil Company Ltd., and Statoil Canada Ltd. for the production of oil from an offshore platform on Canada's east coast. ${ }^{11}$ On the natural gas side, Sable Island Offshore Energy Project is a joint venture involving ExxonMobil Canada Properties Ltd., Shell Canada

“About Syncrude,” online: Syncrude Canada Ltd <http://www.syncrude.ca/users/folder.asp?Folder ID $=5617>$.

“Shell’s Heavy Oil Business Overview," online: Shell Canada <http://www.shell.ca/home/content/canen/aboutshell/our_business_tpkg/business_in_canada/upstream/oil_sands/overview/>.

"About Hibernia,” online: Hibernia <http://www.hibernia.ca/about.html>. 
Limited, Imperial Oil Resources, Mosbacher Operating Ltd., and Pengrowth Energy Corporation. ${ }^{12}$ Some of these joint ventures have operated for decades. ${ }^{13}$

While joint ventures have been regularly utilized in the energy industry, the recent activity utilizing joint ventures (particularly with respect to the development of oil sands and shale gas projects and related infrastructure) and the size of those joint ventures is unprecedented. ${ }^{14}$ Since BP plc and Husky Energy Inc. formed a joint venture in late 2007 for an oil sands facility and a refinery, the Canadian energy industry has seen an amazing number of significant joint ventures. These joint ventures include: (1) Athabasca Oil Corporation and PetroChina Company Ltd., with respect to the development of the MacKay River and Dover thermal energy oil sands projects; (2) Penn West Petroleum Ltd. and China Investment Corporation to develop bitumen assets in northern Alberta; (3) Nexen Inc. and Japan's Inpex to develop shale gas lands in the Horn River, Cordova, and Liard basins in northeastern British Columbia; (4) Talisman Energy Inc. and South Africa’s Sasol Ltd. to develop shale gas assets in Farrell Creek and Montney basins in British Columbia and to consider the viability of gas to liquids facilities in British Columbia; (5) Penn West Petroleum Ltd. and Mitsubishi Corporation to develop shale gas formations and conventional natural gas in northeastern British Columbia; (6) Encana Corporation and Korea Gas Corporation to develop shale gas properties in the Horn River and Montney basins; (7) PETRONAS and Progress Energy Resources Corp. to develop Montney shale gas holdings and to establish a liquified natural gas (LNG) export joint venture; and (8) Encana Corporation and Japan's Toyota Tsusho Corporation, with respect to the development of a heritage coal bed methane field. ${ }^{15}$ Joint ventures are also being used to develop shale gas infrastructure, as evidenced by the joint venture between Kohlberg Kravis Roberts \& Co. and Quicksilver Resources Inc. to construct and operate natural gas midstream services in the Horn River area, and projects proposed by Apache Canada Ltd., Encana Corporation, EOG Resources Canada Inc. (as proponents of Kitimat LNG), Royal Dutch Shell plc, Mitsubishi Corporation, and Korea Gas Corporation, among others, to develop LNG facilities and related transportation infrastructure on Canada's west coast. Similar joint ventures are being used south of the border to develop shale gas assets in various regions in the United States. ${ }^{16}$

“Sable Project Operations Overview,” online: ExxonMobil <http://www.soep.com/cgi-bin/getpage? pageid $=1 / 0 / 0>$.

13 The Syncrude Consortium was formed in 1964, Athabasca Oil Sands Project started up in 2003, oil production from Hibernia began on 17 November 1997, and gas production from Sable Offshore Energy Project commenced 31 December 1999.

14 Nathan Vanderklippe, "Doing the deal: Joint ventures in the oil patch tough to pull off," The Globe and Mail (22 February 2012), online: The Globe and Mail <http://www.theglobeandmail.com/report-onbusiness/industry-news/energy-and-resources/doing-the-deal-joint-ventures-in-the-oil-patch-tough-topull-off/article2346809/>.

15 See Appendix A for a more detailed list of some of the more significant joint ventures in the Canadian energy industry in the past few years.

16 For example, Devon Energy Corporation recently reached a deal with China's Sinopec, in which Devon gave up a third of its interest in five developing fields for \$2.2 billion and Total SA and Chesapeake Energy Corporation recently agreed to a $\$ 2.3$ billion to develop fields. See Devon Energy Corporation, News Release, "Devon Energy Announces \$2.2 Billion Transaction on Five New Venture Plays” (3 January 2012), online: Devon Energy Corporation <http://www.dvn.com/Newsroom/Pages/News Release.aspx?id=1644020>; Chesapeake Energy Corporation, News Release, "Chesapeake Energy Corporation Announces Completion of \$2.32 Billion UTICA Shale Joint Venture Transaction with Total E\&P USA, Inc.” (3 January 2012), online: Chesapeake Energy Corporation <http://www.chk. com/NEWS/Articles/Pages/1643884.aspx>. 
The trend towards these joint ventures does not appear likely to end any time soon. Among the current announcements for proposed joint ventures, Cenovus Energy Inc. is looking to sell off part of its oil sands interests that could bring in an estimated $\$ 1$ billion to \$3 billion and Encana Corporation announced recently that it is seeking a "partner" to help develop a number of properties in the US and Canada with potential for lucrative oil and liquids-rich natural gas. ${ }^{17}$

But joint ventures can be enormously complicated and, therefore, do not always work. Perhaps the best evidence of that difficulty was Encana Corporation's failed joint venture with PetroChina Company Ltd. (valued at \$5.4 billion) with respect to the Montney shale play that would have formed the largest Chinese energy investment in North America. However, that deal was replaced with the nearly \$3 billion deal pursuant to which Mitsubishi Corporation acquired a 40 percent stake in Encana Corporation’s Cutbank Ridge assets, a major British Columbia gas field. This transaction brought Encana both upfront money and an agreement from Mitsubishi to fund much of the development. While there may be another suitor waiting in the wings like there was for the Encana Cutbank Ridge assets, that is not always the case. There are a vast number of proposed joint ventures in the energy industry that never make it across the finish line.

\section{RATIONALE FOR FORMING JOINT VENTURES}

A number of the recent significant joint ventures in the energy industry have involved Chinese, South Korean, Japanese, Malaysian, and other Asia Pacific investors that have spent billions of dollars to lock up parts of Canada's oil and gas reserves. The level of investment into Canada by the Asia Pacific region has been substantial and all indications are that this investment will continue. It is useful to briefly consider the rationale that may be behind many of these joint ventures.

With respect to natural gas, Asia Pacific countries, in particular South Korea and Japan, use significant amounts of liquefied natural gas and have a growing appetite for natural gas. This has been exacerbated by Japanese energy companies as they look to tap overseas energy sources following 2011's tsunami and nuclear meltdown in eastern Japan. ${ }^{18}$ In contrast, the development of shale gas in the US has meant that there is far less need for Canadian natural gas in the US and has created a glut of natural gas in North America. Consequently, Canada needs to find new markets for its natural gas. This makes Canada and Asia Pacific energy entities logical business partners.

There is a relatively familiar pattern to the investment by Asia Pacific entities into Canadian shale gas plays. Since these projects use expensive hydraulic fracturing technology that makes the development of the resources expensive, the Asia Pacific entities bring money to the table. The Asia Pacific entities typically make an up-front payment along with a

17 Luke Pachymuthu, “Encana looks for partners in a number or regions,” Reuters (29 March 2012), online: Reuters <http://www.reuters.com/article/2012/03/29/encana-idUKL2E8ET3X420120329>.

18 Brian Baxter, “Calgary Firms Lead as Japan’s Mitsubishi Invests in Canadian Shale,” The American Lawyer (20 February 2012), online: The American Lawyer.com < http://www.americanlawyer.com/Pub ArticleTAL.jsp?id=1202542958511\&Calgary_Firms_lead_as_Japans_Mitsubishi_Invests_in_Canad ian_Shale\&slreturn=20120807104925>. 
commitment to help fund the development of shale gas properties. This allows the properties to be developed on an accelerated basis, while simultaneously allowing the joint venturer holding the shale gas properties to reduce its financial pressure and redeploy its capital. This is a particularly useful outcome where an entity is facing debt issues. Often the Asia Pacific entities will also offer their expertise to help study infrastructure projects needed to transport Canadian natural gas to the Asia Pacific region in the form of LNG. In return, Asia Pacific entities get access to expansive Canadian energy resources and get exposure to the technology required to develop these assets that can potentially be redeployed to develop similar assets in their home countries. ${ }^{19}$

There are, of course, many other reasons for entering into joint ventures in the energy industry. Commercial considerations often drive entities to unite. For example, in certain instances it may be necessary to joint venture with a specific type of entity in order to get access to the bidding process on a project or to get a project approved. In the infrastructure industry, a number of joint ventures are created with First Nations in northern Canada for such purposes, as many projects require First Nations involvement given their dependence on First Nations support for their success. This practice is also common with respect to the development of resource plays in many areas of the world where companies joint venture with governmental or quasi-governmental entities to secure significant resource concessions.

Entities also use joint ventures as a means to diversify. Joint ventures can increase the chances of success for smaller enterprises by partnering with larger, more sophisticated entities. Where the costs of projects are high, joint ventures allow entities to share the burden of the project (as well as the resulting profit). The smaller entity may also be able to leverage off of its relationship with the more significant entity in other areas. This is a common rationale for joint ventures in the conventional oil and gas and renewable energy sectors.

From an investor's perspective, a joint venture may be preferable to financing due to the level of influence and control that can be obtained through a joint venture structure. Additionally, an entity may be able to access such things as technology and operational expertise through a joint venture that it could not access through financing. Joint ventures may also allow some buyers to get into a market without triggering the concern created by outright takeovers. ${ }^{20}$ The list of transactions in Appendix A makes it clear that joint ventures have been the preferred choice among foreign entities for making significant investments into the Canadian oil and gas industry today.

\section{FORMS OF JOINT VENTURES}

The three primary forms of joint ventures are corporations, partnerships (including limited partnerships), and contractual joint ventures. Joint venturers are able to obtain similar results with respect to any of the forms used by means of contractual arrangements. Therefore, the form of joint venture that is chosen will often depend on considerations such as taxes and the ability to limit liability to third parties. 


\section{A. Joint VENTURE CoRporation}

A joint venture corporation is created when joint venturers incorporate a corporation where the joint venturers are the shareholders. The joint venturers contribute assets to the corporation which then owns and controls the assets. In these types of agreements, there is no risk that a joint venture corporation is construed as an alternative form of joint venture, such as a partnership, and it is not necessary to state the objects of the corporation. Furthermore, since the joint venturers are shareholders, absent other arrangements such as parental guarantees to support a joint venture corporation which is not creditworthy, the joint venturers have limited liability.

Joint venture corporations will also be subject to the rules in the relevant corporate statutes. These rules impose obligations, such as annual reporting, annual financial statements, and maintenance of a registered office and corporate records, and address governance matters, including voting thresholds on material decisions, duties of officers and directors, and a number of other matters. These rules impose certain liability on directors of the joint venture corporation, including liability for unpaid income taxes (including failure to remit source deductions), environmental offences, and employee wages. In such instances, directors will need to ensure they are adequately protected by statutory indemnity provisions, directors' and officers' insurance, and any contractual indemnity offered by the joint venturers. To the extent the joint venturers do not wish to be bound by these rules, joint venturers can customize their relationship by contract through a unanimous shareholders agreement. Such agreement allows certain powers of the directors (including the management of the business of the corporation) to be ceded in whole or in part to the joint venturers.

Joint venture corporations are beneficial in that they are familiar and well understood, and there is an established body of law applicable to them. ${ }^{21}$ Such body of law includes a number of built-in protections for minority joint venturers, including judicial discretion to "wind up," judicial discretion to make any order a court sees fit, derivative actions, compliance and restraining orders, and the oppression remedy. In contrast, the key to minority protection for joint venture partnerships and contractual joint ventures is in the terms of the contract.

From a tax perspective, the joint venture corporation is a separate legal entity and is a taxpayer distinct from the joint venturers. That treatment can result in double taxation, but the tax-free treatment of inter-company dividends essentially addresses this concern. Perhaps a bigger concern from the tax perspective is that the tax liability of a joint venture corporation is separate from that of the joint venturers. Consequently, a joint venture corporation is prevented from offsetting its losses directly against the income of the joint venturers or vice versa. However, it may be beneficial to use a joint venture corporation where the joint venture corporation is able to use the small business deduction or refundable investment tax credits. Furthermore, joint venture corporations have the opportunity to transfer assets on a tax deferred "rollover" basis provided the transferee is a taxable Canadian corporation. Additionally, a joint venture corporation enables the sale of shares and enjoys 
capital gains treatment, rather than selling assets that may give rise to business income. This is generally, but not always, advantageous.

\section{B. JOINT VENTURE PARTNERShiP}

A joint venture partnership is created by the actions of an agreement between the joint ventures, rather than through the rules of a statute as in a joint venture corporation. As such, there is no requirement that the partnership be registered to bring it into existence. However, once the joint venture partnership is created, the partnership is governed by the applicable provincial partnership legislation. That legislation establishes the basic terms of the partnership relationship between the joint venturers. Unlike the statutes applicable to a joint venture corporation, legislation concerning joint venture partnership leaves much of the details of the relationship to be settled by agreement amongst the joint venturers. Like a unanimous shareholders agreement for a joint venture corporation, a partnership agreement allows joint venturers to customize their relationship and supplement the applicable statutory rules.

Perhaps the most significant rule with respect to a joint venture partnership is the requirement that each joint venturer is the principal and agent for the other joint venturers and must exercise discretion as agents with a view to the best interests of the partnership as a whole. Consequently, a joint venturer must be very familiar with the joint venturers with whom it is getting into business. In order to protect itself, the joint venturer may give itself limited liability protection through incorporation of a corporation to hold the partnership interest (but that may be problematic from a tax perspective). A joint venturer may also reduce its risk under a joint venture partnership by contracting out of the ability of one joint venturer to bind the joint venture partnership to third party contracts provided the third parties are aware of such limitation. Joint venturers can also use contractual indemnities and insurance to provide protection.

A limited partnership is a specific type of joint venture partnership. Unlike partnerships generally, a limited partnership is created entirely through the operation of statute and is formed when a declaration of limited partnership is filed with the registrar in accordance with the applicable legislation. ${ }^{22}$ It is a good alternative where one or more passive investors do not want involvement with the ongoing management of the joint venture. Often where there is a limited partnership, a corporation will be created by the limited partners to act as general partner and assume general liability for the limited partnership. In those cases, there will generally be a unanimous shareholders agreement at the general partner level and a partnership agreement among the partners, including the general partner. Consideration needs to be given to which decisions need to be made under each of the unanimous shareholders agreement and the partnership agreement and the level of consent required for each such decision. Because of the limited liability of limited partners, a joint venture partnership carried out as a limited partnership is subject to more onerous formal requirements than an ordinary joint venture partnership. Limited partners taking part in control of the limited partnership will lose their limited liability status. ${ }^{23}$ 
Under the Income Tax Act, ${ }^{24}$ a joint venture partnership is a "person” for certain purposes. The income or loss of the joint venture partnership is calculated as if it was a separate person from its joint venturers, and the income or loss is allocated to the joint venturers according to their partnership interests. Also, like joint venture corporations, partnerships have the opportunity to transfer assets on a tax deferred "rollover" basis and give joint venturers the opportunity to sell their interest as distinct from their assets and realize a capital gain rather than income. As referenced above, to the extent a joint venturer incorporates a corporate subsidiary to hold its interest in the joint venture partnership, the joint venturer may lose the benefit of loss flow through for tax purposes.

\section{CONTRACTUAL Joint Venture}

In a contractual joint venture, a contract governs the relationship between joint venturers. Unlike a joint venture corporation or partnership, no separate legal entity is created in a contractual joint venture. Rather, a contractual joint venture is completely a creature of contract without the necessity of meeting any formal requirements. The contractual joint venture can be completely customized using any governance structure that the parties determine appropriate. Furthermore, the assets of a contractual joint venture continue to be owned by the parties themselves and not by a separate legal entity. Similarly, a contractual joint venture is not able to raise capital through equity contributions by its joint ventures (as can be done in a joint venture corporation or partnership), although a contractual joint venture can still obtain third party loans in a similar fashion to joint venture corporations and partnerships.

To the extent a contractual joint venture is desired, the parties need to be careful not to inadvertently create a partnership, in which event joint venturers would become subject to the applicable rules governing partnerships (including joint liability). ${ }^{25}$ As noted above, the Province of Alberta is currently looking at clarifying the matter in an effort to avoid such a result. ${ }^{26}$ To put themselves in the best position with respect to such a determination, joint venturers should be clear in their intent and attempt to retain their independence as much as possible. Similarly, where joint venturers in a contractual joint venture proportionally share in all economic benefits relating to an asset of a joint venturer, joint venturers may be deemed to be co-owners of the assets. In such event, there will be a deemed disposition of a beneficial interest in the applicable asset from one joint venturer to another. This will give rise to an income or gain on such assets for tax purposes.

From a tax perspective, a contractual joint venture is not a separate entity. In determining its tax liability, each joint venturer takes into account its revenues and expenses from the joint venture. Since each joint venturer owns its own assets in a contractual joint venture, each joint venturer will also realize its shares of revenues and claim its expenses without regard to the tax filing position taken by the other joint venturers. 
While Canadian entities may prefer to use a joint venture partnership structure in order to realize certain tax benefits, such a structure may not be acceptable to foreign entities. For example, foreign entities often are not familiar with the concept of joint ventures or partnerships. Asia Pacific entities may have accounting issues with joint venture partnerships as well. Often those entities are much more comfortable with a joint venture corporation, given their familiarity with the structure of a corporation. While there is a mix as to the type of structure utilized, the most common form of joint venture in the energy industry appears to be the contractual joint venture, given the flexibility created by that form of joint venture and the familiarity of the structure among participants in the Canadian energy industry. ${ }^{27}$

\section{REgUlatory CONSIDERATIONS}

Some matters that can impact the likelihood of a joint venture being subject to regulation are: (1) the size of the joint venturers; (2) the size of the joint venture being created; (3) the employment of a workforce; (4) participation in a regulated industry; (5) competition between the joint venturers in a horizontal relationship; (6) a supplier and customer relationship between joint venturers; and (7) the presence of a non-Canadian participant. Regulatory concerns should be addressed at the time of structuring the joint venture to avoid future problems. Among other things, there may be pre-notification requirements, making it important for joint venturers to consider applicable regulations from the outset. Regulatory considerations also require ongoing attention during the life of the joint venture. Joint venturers must be aware of the regulatory regimes governing the operation of the joint venture, especially any industry-specific regulation relating to entering into a joint venture. ${ }^{28}$ Where one or more of the joint venturers is a foreign entity, consideration must also be given to international law issues and the legal regime in the foreign entity's home jurisdiction, including foreign antitrust laws, foreign investment and trade regulations, foreign labour and employment laws, and foreign laws on technology transfer.

The Investment Canada Act will also be a consideration when dealing with foreign entities. The purpose of the Investment Canada Act is to "provide for the review of significant investments in Canada by non-Canadians in a manner that encourages investment, economic growth and employment opportunities in Canada."29 This is accomplished by ensuring that the acquisition of control of large Canadian businesses does not occur unless it is likely to be of "net benefit" to Canada. ${ }^{30}$ If a foreign entity acquires control of a Canadian business, the investment may be either reviewable or notifiable, depending on the book value of assets of the Canadian business and the citizenship of the people who ultimately control the investor. If the transaction is reviewable, the transaction cannot be completed until the Minister of Industry is satisfied that the transaction is likely to be of net benefit to Canada. However, if it is notifiable, the investor must simply notify the Director

John B Connally IV \& Patrick T Maguire, "Recent Trends in Joint Ventures for Shale Oil and Gas and other Capital-Intensive Oil and Gas Projects” (Paper delivered at the 57th Rocky Mountain Mineral Law Institute, 21-23 July 2011), 57 Rocky Mountain Mineral Law Institute 18-1 at 18-4.

28 There are a number of regulations that may be applicable to Canadian energy joint ventures, but this article does not propose to discuss such regulations. Rather, this article provides only a very cursory look at considerations under the Investment Canada Act, RSC 1985, c 28 (1st Supp) and the Competition Act, RSC 1985, с C-34.

29 Investment Canada Act, ibid, s 2. Ibid, s 16(1). 
of Investments at Industry Canada within 30 days following closing, and provide certain, largely statistical, information. ${ }^{31}$

An investment is reviewable under the Investment Canada Act if it is an investment to acquire control of a Canadian business where the value of the assets of the business exceed a specified threshold. For a direct acquisition of control (in other words, the acquisition of substantially all of the assets of the Canadian business or an operating segment thereof or the acquisition of control of an entity organized under Canadian law by way of the sufficient shares or voting equity to constitute control within the meaning of the Act), the applicable thresholds are CDN\$5 million for a cultural business or an acquisition by an investor not controlled by nationals of a World Trade Organization (WTO) member country or CDN\$330 million for transactions that close in 2012 involving a WTO investor and a non-cultural business. ${ }^{32}$ Where a transaction is reviewable, joint venturers require approval of the Minister of Industry. ${ }^{33}$ Depending on the precise structure of the joint venture, and whether assets or equity of a pre-existing Canadian business are involved, even the formation of a new joint venture could be subject to review under the Investment Canada Act, and legally binding undertakings to the Minister of Industry may be required to be given regarding the "net benefit" factors listed in section 20 of the Act (regarding such things as the impact on employment, capital expenditures, exports, output, productivity, competition, Canadian involvement in management and the Board, location of head office, philanthropic contributions, and compatibility with federal and provincial policies). ${ }^{34}$ The formation of a new Canadian business is also required to be notified to Industry Canada under the Investment Canada Act. ${ }^{35}$

The provisions of the Competition Act apply to the formation of many joint ventures, as well as to the acquisition of interests in existing joint ventures. Joint ventures, by their nature, require collaboration. That collaboration may be perceived as diminishing competition, since collaboration between horizontal competitors reduces the number of competitors and collaboration between vertical entities, such as a joint venturer and its supplier, may impair the ability of competitors to obtain necessary assets where supply alternatives are limited. Where competition is lessened, the implications under the Competition Act must be clearly understood by the joint venturers. The three most applicable provisions of the Competition Act are the civil merger provisions, the criminal conspiracy provisions, and the civil competitor collaboration provisions. ${ }^{36}$

As noted above, joint ventures of a certain structure and size may trigger pre-merger notification requirements. To determine whether pre-notification is required, joint venturers must consider the nature of the transaction (formation of an unincorporated joint venture or acquisition of assets or shares or an interest in an unincorporated business), the size of the

Ibid, s 12 .

Ibid, ss 14, 14.1. The WTO threshold is indexed annually to account for inflation.

Ibid, ss. 2, 11-25.

Ibid, s 14.

Ibid, s 11 .

Competition Act, supra note 28, ss 109-112, 45, and 79, respectively. For guidelines into the Competition Bureau's approach to determining whether to assess a joint venture under the criminal conspiracy provision, civil agreements provision, or other provision of the Competition Act, please see Competition Bureau Canada, Enforcement Guidelines: Competitor Collaboration Guidelines (Gatineau: Competition Bureau Canada, 2009) [Competitor Collaboration Guidelines]. 
parties (combined assets in Canada or annual gross revenues from sales in, from, or into Canada greater than CDN\$400 million, including all affiliates), and the size of the transaction (assets in Canada or annual gross revenues from sales in or from Canada generated from those assets greater than CDN\$77 million). ${ }^{37}$ With respect to the acquisition of an interest in an unincorporated combination carrying on an operating business in Canada, the acquirer must also be gaining an interest entitling it to greater than 35 percent of the profits, or the assets of the target combination on dissolution are greater than 50 percent if the 35 percent threshold is already exceeded. ${ }^{38}$ Where those thresholds are met, pre-merger notification will be required, subject to certain exceptions applicable to some joint ventures under the Competition Act. ${ }^{39}$ Whether or not a transaction is subject to pre-merger notification, Canada's Commissioner of Competition (the Commissioner) has jurisdiction to review and challenge any merger within one year of its completion, on the basis that the merger substantially lessens or prevents competition in a properly defined antitrust product and geographic market or is likely to do so, unless prior to the merger the Commissioner issues an advance ruling certificate in respect of the transaction. ${ }^{40}$

As civil matters, mergers result in actions by the Commissioner before the Competition Tribunal for remedial order. However, given the level of competition in the energy industry (and in particular the oil and gas industry), it is unlikely that joint venturers will be found to prevent or lessen competition where the joint venture entails the construction of new facilities, provided that the new facilities do not compete proximately with those of either of the joint venturers. There is a statutory efficiency defence in merger review such that joint ventures creating efficiency gains may have further protection. ${ }^{41}$

No such defence exists with respect to conspiracy. As a criminal matter, conspiracy offences can result in substantial penalties and private rights of action where joint venturers are found to have conspired to take certain actions, such as price fixing, or make other agreements to restrict competition. ${ }^{42}$ Care must be taken, accordingly, when structuring a joint venture to ensure that its scope is limited to the functions which neither party would be willing to undertake on its own, and do not stray into co-operative marketing or other areas where it could be alleged that competitors have agreed on prices, to allocate customers or markets, or to reduce production or supply, contrary to section 45 of the Competition Act. However, section 45 is subject to a defence to the effect that a provision of a joint venture agreement (or any agreement between potential or actual competitors) that is "ancillary and necessary" to another larger agreement that does not in itself violate the law is not subject to criminal prosecution. ${ }^{43}$

Section 90.1 of the Competition Act enables the Commissioner to bring a civil application to the Competition Tribunal asking for a prohibition order in respect of agreements between competitors that substantially lessen or prevent competition. Accordingly, even if an aspect

Competition Act, ibid, ss 109(1), 110(2)-(9). The "size of transaction" threshold may be indexed annually to account for inflation.

Ibid, s 110(3)(b).

Ibid, s $110(4.1)$.

Ibid, ss 92, 102.

Ibid, s 96.

Ibid, ss 45-46.

Ibid, s 45(4). 
of the joint venture agreement is ancillary and necessary to the joint venture agreement and is, therefore, shielded from criminal liability, the Commissioner may still challenge aspects that are likely to substantially lessen or prevent competition. The Competition Bureau has issued the Competitor Collaboration Guidelines, which can assist in identifying aspects of joint ventures which may attract Competition Bureau scrutiny, and parties are advised to seek legal advice on this aspect of a joint venture early in the planning stages. ${ }^{44}$

\section{JOINT VENTURE DOCUMENTATION}

While a number of joint venture arrangements in the energy industry utilize standard form joint venture documentation, there is no standard form for the more complex joint venture arrangements of the type contemplated above with respect to the oil sands or shale gas projects. Nor does standard form joint venture documentation exist in the power sector. This is, in part, due to the different structures that are utilized by the joint venturers, but it is also a function of the unique nature of each such joint venture.

Often joint ventures with respect to oil sands or shale gas projects attempt to incorporate aspects of various forms of standard operating agreements, including the Canadian Association of Petroleum Landmen (CAPL) forms of Operating Procedure ${ }^{45}$ or the Association of International Petroleum Negotiators (AIPN) Model International Operating Agreement. ${ }^{46}$ Foreign entities are often quite familiar with the AIPN form of agreement, so that agreement has some appeal to them, but Canadian entities may be less familiar with it. These forms generally work well for conventional oil and gas exploration, but none of these agreements are great fits for joint ventures being created with respect to oil sands and shale gas. While concepts such as the scope of the joint venture, the designation and replacement of the operator, functions of the operator, and the formation of an operating committee are useful, concepts such as independent operations may not work for long-term arrangements to develop a single large project. Likewise, provisions with respect to work programs and budgets may be too simplistic given the vast expenditures occurring with respect to the largescale oil sands and shale gas projects. Consequently, some customization is ultimately required in connection with the particular joint venture. The result has generally been a hybrid approach that incorporates certain concepts from the standardized operating agreements, but includes a more comprehensive set of provisions, often detailed across a number of interrelated agreements.

While no existing standard form agreement currently works for the large scale oil sands and shale gas projects, the extensive number of arrangements in recent times has resulted in some consistent terminology within the various customized agreements. Many of the same concepts are being captured from deal to deal. As a result, while a standard agreement is unlikely, greater standardization of concepts appears to be emerging. Often these concepts are captured in an umbrella joint venture agreement that extends over a number of related 
agreements. These concepts are also extending into other energy joint ventures, such as those relating to the development of LNG facilities and other energy infrastructure projects. ${ }^{47}$

\section{KEY COMMERCIAL CONSIDERATIONS}

Negotiating, structuring, and forming a joint venture can be a complex and multifaceted task, particularly with respect to oil sands and shale gas projects. Joint ventures are often more complicated than outright purchase and sale arrangements, as joint ventures need to take into account the ongoing relationship of the parties and the vast array of contingencies that can arise over the term of that relationship. A joint venture is more likely to be successful where there are complementary assets, expectations are clearly outlined, incentives aligned, and parties pay attention to key issues. Many joint ventures are not ultimately consummated once parties work through the myriad of issues to determine their level of compatibility. However, the failure to begin a joint venture is often much more palatable for an entity than the consummation of a bad joint venture.

The first step in discussions regarding a joint venture is to work out a term sheet that highlights the key considerations on which each of the potential joint venturers can agree. If the parties are unable to agree on certain fundamental terms, then there is no point in proceeding with joint venture negotiations. Negotiation of a term sheet brings important issues to the forefront and can often pre-empt an expensive and time-consuming negotiation that may be doomed to failure. A term sheet usually addresses key provisions such as the parties, the nature of the agreement, the business of the joint venture, the operator, governance, form and terms of investment, the sharing of profits, termination events and the consequences thereof, the ability to exit the arrangements or the terms by which new entrants can be added, confidentiality, non-competition, and dispute resolution. The term sheet will also generally set out any conditions that must be satisfied in order for the transaction to occur, any due diligence that is to be performed, and a period during which exclusive negotiations will proceed between the parties. The definitive joint venture documentation then specifies the commercial arrangements in detail. Often where joint ventures fail at the definitive documentation stage, the parties did not spend enough time at the term sheet stage making sure that they were of like mind on key aspects.

Once it is time to document the terms and conditions of the joint venture in a definitive agreement, or a series of definitive agreements, the following matters are some of the more important considerations to be addressed in that definitive documentation.

\section{A. SCOPE OF THE JOINT VENTURE}

The scope of the joint venture should be the first determination by the parties. Generally, the joint venturers have similar ideas as to the nature of the agreement. However, once joint venturers start discussing the details, they may differ as to the geographical area that the joint venture is to cover, the type of operations, or the future opportunities to which the joint venture is entitled. The scope should be clearly defined from the outset and should consider

47 In addition to a joint venture agreement, a purchase and sale agreement is required where an entity is buying an interest in assets from another entity for the purpose of creating a joint venture. 
rights of the parties to, among other things, expand the geographical areas covered by the joint venture, the operations undertaken by the joint venture, or the scope of the activities in which the joint venture is engaged. For example, with respect to shale gas projects, considerations may extend to the development of midstream assets necessary to link properties with markets, the development of LNG facilities ultimately needed to transport natural gas to overseas markets, or marketing activities with respect to joint venture production. ${ }^{48}$ Absent agreement as to such expansions, it should be made clear that the scope of the joint venture is limited to those matters specifically identified and agreed upon.

In connection with the scope of the joint venture, the joint venturers should determine the level of competition with the joint venture in which the joint venturers may engage. At an early stage, joint venturers should negotiate which corporate opportunities must be referred to the joint venture and which can be pursued by individual joint venturers. Exclusivity covenants define the exclusive business of the joint venture and often set geographical limits and time limits for exclusivity to be enforced. Joint venturers would be required to refer opportunities with respect to specified locations and during specified times. These provisions can also be used to limit the exclusivity and non-competition clauses where the joint venturers compete in similar markets and need to be able to continue their business. Issues around non-competition become particularly sensitive where a joint venturer has assets in different zones in the same lands as the joint venture or in lands adjacent to the joint venture, as there is a real potential for conflicts in those instances.

Restrictions on competition impact the independent operations in which joint venturers can engage. As noted above in Part VI, independent operations are common provisions in CAPL and AIPN forms of agreement but may be less applicable to joint ventures that involve the long term development of a significant project or projects involving large expenditures of capital. In such instances, it is typical for joint venturers to restrict each other from performing independent operations. Such restrictions are particularly important during any carry period. To the extent independent operations are permitted by the joint venturers at some point, structuring the rights becomes difficult. The joint venturers will not generally be able to rely on traditional penalty arrangements. Often a sale of an interest from a nonparticipating joint venturer to the proponent of the independent operation will be required. Treatment of such rights to independent operations is important, as the joint venturers will want to ensure that all parties are committed and are properly incented to devote resources to the joint venture. ${ }^{49}$

\section{B. GOVERNANCE OF THE JOINT VENTURE}

Often a critical consideration for a joint venturer is the level of involvement in the management and operations of the joint venture. There is a wide spectrum of potential involvement, with some joint venturers taking a passive approach to their investment with very limited involvement in management and operations, other joint venturers wanting unanimity over any decision of any significance, and still other joint venturers wanting 
control over certain critical issues like capital expenditures or technology and expertise, but little involvement in operational matters like operating budgets and drilling programs.

It is typical for a joint venturer's input into the management of the joint venture to be consistent with its level of investment. Indeed, that is often the starting point for negotiations with respect to voting and control. However, there are a number of instances where the level of voting and control will not match the level of investment. In some instances, a joint venturer has an ownership interest that it maintains for the purposes of appearance, but it may have practically no significant rights as to the management or operation of the joint venture. In other cases, a joint venturer may have a limited ownership interest but want to maintain at least equal participation on operational or management issues to ensure that its interest in the joint venture is adequately protected.

Where unequal voting and control rights exist, minority joint venturers must be particularly careful in structuring their arrangements. There is a significant risk for holders of a minority interest, in that unequal control can lead to the abuse of the minority interest joint venturer. That minority position may also result in the minority joint venturer being less engaged in the joint venture. Both of these situations are likely to result in heightened levels of tension between the joint venturers. To help mitigate this risk, joint ventures are often structured to give minority joint venturers veto rights with respect to key decisions. These decisions often include such matters as appointment and removal decisions with respect to management and operations, changes to the scope, term, or structure of the joint venture, financial matters such as the approval of budgets, the making of significant capital expenditures or the increase in expenditures beyond an approved amount, the admission or removal of joint venturers, the sale of significant assets of the joint venture, the incurring of any debt by the joint venture, the entering into of certain contracts by the joint venture, changes to any required contributions by the joint venturers or other amendments to the joint venture's governing documents, or the distribution of any proceeds to joint venturers. The matters providing for veto rights are often strategic in nature and are not intended to impact daily management and operations functions of the joint venture. Given the importance of such veto rights, joint venturers need to spend significant time ensuring they are satisfied with such rights.

In contrast, where there is equal voting and control rights that require a consensus on all issues, the decision-making process can be cumbersome and result in frequent deadlocks. This is problematic in that, given the size and nature of certain joint ventures, "stalemate isn't usually an acceptable result." ${ }^{\text {"0 }}$ One alternative to such arrangement is to give each joint venturer control over specific aspects of the joint venture. Another alternative is to hire an independent third party to perform the management function. However, joint venturers may have considerable concerns over the level of commitment of an independent third party or as to the alignment of such independent third party's views and goals with those of the joint venturers themselves. Consequently, an independent third party is often not a practical alternative. Given the potential for problems with deadlocks and other dysfunctional behaviour between joint venturers, the procedural rights given to joint venturers to attend and 
call meetings to pursue resolution of conflict and the selection of any dispute resolution mechanisms will be important considerations.

The type of joint venture will dictate the type of governance body. Typically, a joint venture corporation will have directors, a limited partnership joint venture will have a general partner with its own directors, and an ordinary joint venture partnership or a contractual joint venture will have an operating or management committee to make key decisions. Like a director, each representative of a joint venturer on such a committee must have authority to make decisions that are binding on the joint venturers. Whatever the form of the governance body, it should be structured in such a way as to take into account the potential for deadlocks, the ability to change members of the body, the role independent members are to play, and the nature of decision making (be it simple majority, super majority, or unanimity for various matters). Obviously, the decision-making process should vary with the importance of the decisions.

In addition to strategic decision-making, the joint venturers need to appoint an operator to perform the operational functions of the joint venture. While it is more typical for one of the joint venturers to act as operator, as noted above, the duties of operators can be split (with each joint venturer responsible for certain defined obligations) or can be performed by a third party. Regardless of how the operatorship is structured, it is imperative that the joint venturers clearly state the authority that is given to the operator, the parameters within which the operator must operate, the standards of operation to be followed, the liability of the operator, and the approvals that the operator must seek from joint venturers. The joint venturers must also address how the operator is to be appointed or replaced, and the rights available to an operator to resign. ${ }^{51}$

\section{CONTRIBUtions AND FINANCING}

The success of a joint venture is often linked to the arrangements with respect to the financial contributions by the joint venturers. How financial contributions are structured can impact the commitment of joint venturers and influence the engagement of joint venturers in the management and operation of the joint venture. Generally speaking, joint venturers will be more committed to the joint venture if they have made significant financial contributions.

The joint venturers' contributions are typically the most significant source of funding. These contributions may be made by up-front payments or ongoing commitments. Contributions typically take the form of cash, capital (shares or partnership interests), assets (including intangibles such as technology and intellectual property), skills, key personnel, or even political contributions. To the extent the joint venture is a corporation or a partnership, the contributions are made directly to the joint venture. With respect to contractual joint ventures, joint venturers designate contributions for use by the joint venture without an actual transfer of such contributions. 
In some cases, a joint venturer may wish to continue to use assets for other purposes. In this event, the joint venturer will retain the rights to certain assets and will lease or licence such assets to the joint venture. Alternatively, a joint venturer can transfer assets on a royalty basis. Where the contribution by a joint venturer takes the form of personnel or administrative services, a services agreement is often utilized. In return for the provision of such services, a joint venturer often receives monetary payments, since taking equity for the provision of future services will not constitute sufficient consideration for the issuance of shares in many jurisdictions. ${ }^{52}$

It is often difficult to value the contribution of assets by joint venturers and frequently there is heavy negotiation surrounding the value of the contributions. In considering a joint venturer's contributions, consideration must be given to both up-front payments and future financial commitments. Future contributions to fund ongoing financial obligations of the joint venture are often made on a pro rata basis having regard to a joint venturer's interest in the joint venture. However, in certain cases, joint venturers may wish to limit their exposure to future contributions, such that a monetary cap or other limitation may be placed on the obligation to make future contributions. Furthermore, where there is financial disparity among the joint venturers, one joint venturer often agrees to carry the other joint venturer with respect to future investments as part of the consideration for the contribution of assets by the other joint venturer.

Where there is a carry component, the carry is typically for less than the full amount of future commitments. This helps to ensure that the carried joint venturer is also financially invested in the joint venture. Likewise, the joint venturer contributing the cash may not obtain its entire interest until all of its funding commitments have been made. This earn-in over time offers some protection to the other joint venturer from a credit perspective. The extent of the carry and the timing of the transfer of an interest in the joint venture are critical considerations for the joint venturers, with the terms of such arrangements often reflecting the relative strength of the bargaining position of the joint venturers.

The summary of the recent significant joint venture transactions in Appendix A reveals a variety of financial arrangements, although many involve the concept of a carry. In such instances, the joint venturer originally owning the assets agrees to sell off an interest in its assets to the other joint venturer for a significant up-front payment (that the receiving joint venturer can use to pay off debts or fund its various capital programs) and a commitment by the other joint venturer to undertake future funding for a specified amount over a specified period of time. In return, the joint venturer providing the funds receives an interest, whether by way of shares, partnership interests, or a working interest in the assets. That interest will vest either concurrent with the up-front payment or over time upon the occurrence of certain events. ${ }^{53}$ shall not be issued until the consideration for the share is fully paid in money or in property or past service that is not less in value than the fair equivalent of the money that the corporation would, have received if the share had been issued for money." Section 27(5) of that Act provides that “" property' does not include a promissory note or a promise to pay given by a person buying a share or a person who deals not at arm's length ... with a person buying a share.” 
The joint venturers must also create a development plan that details funding commitments. The plan will generally outline the payments to be made for a specified term, the timing of the payments, and the proposed activities associated with those payments. This plan helps to ensure the development occurs in accordance with the agreed upon timing. The plan may also address the development of any related infrastructure. The degree to which the plan is binding often depends on the nature of the joint venture and whether or not a carry is still applicable to one or more of the joint venturers. The joint venturers typically agree to review the plan periodically (often on an annual basis). The portion of the plan relating to the current year would generally contain a more detailed annual work program and budget for the operator to perform. That program would need to comply with the governance mechanism for the joint venture. The consequences of failure by the operator to meet its obligations under the annual work program would generally also be provided. ${ }^{54}$

To the extent a joint venturer is unable or unwilling to meet its obligations with respect to future contributions, the joint venturers need to set out consequences. Such a failure will generally constitute an event of default that triggers remedies such as a dilution right to purchase all or part of the interest of the defaulting joint venturer (creating a reallocation of interest in the joint venture), the payment of such default amount by the non-defaulting joint venturer as a loan to the defaulting joint venturer that is accompanied by a prescribed interest rate, the right to take and dispose of a defaulting joint venturer's share of production, or the suspension or loss by the defaulting joint venturer of certain rights (such as voting, receipt of certain payments, and receipt of information) for the duration of the default. The rights given to joint venturers in such events need to be carefully considered, and often such rights vary with the stage of the joint venture. To the extent the remedies are excessive, they may be construed to be a penalty and, therefore, unenforceable. As such, a prior right to cure often accompanies such remedies to make them more palatable to the courts.

Joint venturers can also get security for such obligations by requesting performance assurances from the other joint venturers. This performance assurance generally takes the form of a parental guarantee or irrevocable letter of credit. The form and amount of the performance assurance will typically depend on the creditworthiness of the joint venturer (or its credit provider) responsible for providing it, both now and in the future. The performance assurance can be realized by a joint venturer in the event the providing joint venturer is in default of its obligations. Performance assurances are particularly relevant where a joint venturer commits to making significant future financial contributions. It should be noted that often a joint venturer challenges the appropriateness of performance assurances since performance assurances can be inefficient from a tax, credit, and cash flow perspective. ${ }^{55}$

In addition to equity contributions, joint venturers may also contribute debt. While equity investments involve the subscription by joint venturers for joint venture interests in return for a residual claim after all creditors have been paid, debt is generally contributed by loan and carries a fixed rate of return. In the event of a bankruptcy of a joint venture, the debt will rank higher than the equity. Therefore, it is less risky than equity investments, but it also has more limited upside than equity. Given that the return on investment is a key consideration 
for joint venturers in determining whether or not to participate in a joint venture, joint venturers often combine contributions by debt and equity to create the right balance for them and an acceptable return on their investment.

It may also be possible for certain joint ventures to obtain third party financing based on the strength of guarantees or credit support by joint venturers, or on the strength of the joint venture itself. In the latter instance of non-recourse financing based on the joint venture's own merits without guarantees or credit support from the joint venturers, the lender will need to take security over the assets of the joint venture. The availability of financing for the joint venture will, ultimately, depend on the level of risk present for lenders. Considerations in that regard often involve the level of equity invested by the joint venturers and the stage of development of the joint venture project.

\section{TERMINATION OR EXIT}

All joint ventures eventually terminate, whether in ordinary course or due to the exercise of termination rights by a joint venturer. Termination or exit by one or more joint venturers may result where the project to be undertaken by the joint venture is completed, where the project is unsuccessful, where there is a change in law or other circumstance that makes the operation of the business illegal or impractical, where management deadlocks occur, where there is a loss of key personnel, where a joint venturer becomes bankrupt, insolvent, or is otherwise in material default, or where a change in capital contribution by the joint venturers is required but one or more joint venturers is unable or unwilling to provide such further capital contribution. The terms around the termination of the joint venture or the exit of one or more joint venturers are critical terms for a joint venture and can have profound impacts on the behavior of the joint venturers.

In considering the termination or exit rights of joint venturers, a balance must be struck between giving parties enough mechanisms to adequately protect their interests and creating too many rights that may make it easy for joint venturers to terminate or exit the relationship, such that they are inadequately committed to the joint venture. Typically, there is an inverse relationship between termination and exit rights, and the governance rights that the joint venturers have, such that the less influence a joint venturer has in the management and operation of a joint venture, the more access such joint venturer will want to termination and exit rights. Furthermore, many joint ventures limit the rights of joint venturers to exercise termination or exit rights until a specific time period passes. Those restrictions are put in place in order to give a joint venture a sufficient opportunity for success. In the end, termination and exit rights need to reflect the unique circumstances of each joint venture.

There are a number of exit rights that can be applied when one or more joint venturers wants to exit the joint venture. The simplest exit right involves the agreement of the joint venturers to terminate the joint venture. Exit rights may also be triggered by specified events, such as the attainment of certain milestones (such as money spent or a specified duration) or a change in strategy, market events, or the control of a joint venturer. It is common in joint ventures for parties to be given unilateral exit rights but be required to provide the remaining joint venturers with a right of first refusal on any proposed dispositions. In those instances, remaining joint venturers would have the right to buy the selling joint venturer's interest on 
the same terms as a proposed sale to a third party. The provision of a right of first refusal may adversely affect the ability of a joint venturer to attract an offer or to obtain the best price for its interest, but it is often an important tool for joint venturers to ensure that they can exercise some control over the entities with whom they get into business.

Joint venturers can also agree in advance on the price for which remaining joint venturers can purchase another joint venturer's interest, either on request by that other joint venturer (a put right) or on demand by the remaining joint venturers (a call right). This buy-sell mechanism may not be practical at the outset of a joint venture where the value of the joint venture is uncertain, but the joint venturers can agree to various mechanisms to price the interest, such as a fair market valuation that is performed by an independent third party.

In addition to the rights noted above, exit rights can include shotgun rights, piggyback rights, and drag-along rights. A "shotgun” clause allows a joint venturer to name a price at which it is willing to either buy the interests of the other joint venturers or sell its interest to the other joint venturers. The other joint venturers must then decide within a specified time to either buy the joint venturer's interest or sell their interest to the offering joint venturer at the stated price. These provisions are favourable to the party with deeper pockets (although which joint venturer that is may change over the duration of the joint venture). These provisions should be accompanied with related provisions that deal with the manner of acceptance and the completion of the purchase and sale. Often this requirement is overlooked or is insufficiently handled, resulting in unnecessary uncertainty for the joint venturers. A shotgun clause is particularly effective where there is a real potential for stalemate among the joint venturers and where the financial position of the joint venturers is relatively similar. The uncertainty surrounding a triggered shotgun clause is often incentive enough for joint venturers to resolve their differences in other ways.

A piggyback right (or tag-along right) requires a joint venturer selling its interest to a third party to obtain an agreement allowing the remaining joint venturers to sell their interests to the third party on the same terms. This right allows the other joint venturers to avoid having to collaborate with an undesirable third party. In contrast, a drag-along right allows a third party to purchase the interest of an unwilling joint venturer if a majority interest-holder agrees to sell its interest in the joint venture. The purchase by the third party of the minority interest would be on the same terms as the third party's purchase of the majority interest from the joint venturer. Drag-along and tag-along rights are most useful where there are minority investors.

Upon termination of a joint venture, the joint venture is dissolved and the assets of the joint venture are distributed. Joint venture corporations contain statutory methods of dissolution, which may or may not be altered by a unanimous shareholder agreement. Other forms of joint ventures will provide for dissolution in their applicable joint venture agreements.

\section{E. Confidentiality AND InTEllectual Property}

While common law protection exists for confidential information shared between joint venturers, parties should address confidentiality considerations in the applicable joint venture 
agreement. ${ }^{56}$ By incorporating confidentiality provisions into such an agreement, a joint venturer can restrict the ability of other joint venturers to use or disclose that joint venturer's confidential information to any other person, subject to any exceptions provided for by the joint venturers in such agreement. Common exceptions include compliance with applicable law, rules of applicable stock exchanges, or disclosure to a joint venturer's shareholders, affiliates, officers, directors, employees, agents, legal counsel, accountants, financial advisors, and other advisors who need to know the confidential information and agree to keep it confidential. Joint venturers may also want to preserve the right to disclose information on a confidential basis to potential acquirers of that joint venturer's interest in the joint venture. Notwithstanding the presence of a confidentiality clause, a person may want to limit the amount of information it shares with joint venturers.

Where it is difficult to define the proprietary information that has been provided by the joint venturers or acquired by the joint venture, joint venturers may need to supplement confidential information with other provisions. In particular, where technology is an important part of a joint venture arrangement, joint venturers may want to include detailed provisions with respect to the ownership, use, and protection of intellectual property. Joint venturers will need to consider who owns technology used or developed by the joint venture and what happens to that technology upon termination of the joint venture. A joint venturer will need to consider how much access it is going to give other joint venturers to its technology and how technology transfer will be implemented.

\section{F. EMPLOYEES}

Issues around the joint venture's workforce are also important when structuring joint ventures. A joint venture can hire its own employees, obtain employees on secondment, or contract with one or more joint venturers or with a third party for the provision of services. In certain cases, a joint venture may want to use a combination of these alternatives.

When considering workforce issues, joint venturers must take the time to understand who will be liable for certain obligations. Absent a clear mechanism in the relevant agreement to address who provides such things as employment benefits, a joint venturer may find itself liable to its former employees. Likewise, a joint venturer may be vicariously liable for any tort committed by its employees, particularly where the joint venturer retains the power to discipline employees, the obligation to remunerate employees, and the power to discharge employees. Joint venturers will only be protected from liability where absolute control over employees is transferred to the joint venture. Even then, joint venturers could be found to be common, related, or associated employers, and responsible for employee obligations. As such, joint venturers will need to be clear as to who is responsible for oversight, training, and compensation of employees. This will be particularly important where part of the rationale for entering a joint venture is the transfer of technology or expertise and a joint venturer wants to have its employees seconded to the joint venture to gain such expertise.

Where the joint venture has its own employees, or where a joint venturer has contributed employees, consideration should be given to adding a covenant that no joint venturer or its 
affiliates can hire or induce any employee of the joint venture to leave his or her employment. This restriction on hiring or soliciting can be extended to suppliers and contractors. Such provisions are particularly critical where the joint venture is highly dependent on the skill of its employees.

Joint venture partnerships often have more complicated workforce issues, since partnerships are not able to engage employees directly. ${ }^{57} \mathrm{~A}$ separate corporation is generally required to be formed by the joint venture partnership to deal with employees. To the extent the partnership is a limited partnership, the general partner would generally be able to perform this function. The workforce issue is also more complicated where employees performing work for the joint venture are subject to a collective bargaining agreement. Numerous labour issues can arise in such instances. ${ }^{58}$

\section{G. Other Provisions}

There are a number of other provisions that are typical for joint ventures. The importance of those provisions often depends on the nature of the joint venture. For example, insurance is often an important consideration, as a joint venture will want to protect the interests of the joint venture. Insurance includes commercial general liability, wrap-up liability coverage (whether project specific or covering all subcontractors), non-owned automobile liability, environmental impairment insurance, professional liability, property and business interruption insurance, crime insurance, directors and officers' liability insurance, key person insurance, and general liability insurance. In some cases, a joint venture may be able to rely on the insurance of its joint venturers.

Likewise, dispute resolution is often an important consideration. This is particularly an issue where joint venturers come from different countries with different legal regimes. Joint venturers may have very different views as to the level of effectiveness of the court system or arbitration. Moreover, the venue for hearing disputes will also be important. For example, notwithstanding that the joint venture assets may be located in Canada, foreign joint venturers may want to have any arbitration held in what is perceived to be a neutral jurisdiction. Generally, dispute resolution involves some level of management discussion before matters can be referred to courts or arbitration. The importance of the dispute may also impact whether the dispute goes before an arbitrator or a court. Where arbitration is agreed to, for some or all disputes, the joint venturers will need to agree on the terms of the arbitration and the procedure to be followed.

Where joint ventures involve the contribution of significant assets (as is generally the case), due diligence considerations are critical. In addition to rigorous due diligence to understand the assets being contributed to the joint venture, representations and warranties should be obtained to ensure that a joint venturer is a valid legal entity with capacity and authority to perform its obligations under the joint venture and that the assets are in

$57 \quad$ J Anthony VanDuzer, The Law of Partnerships and Corporations, 2d ed (Toronto: Irwin Law, 2003) at 11, 28. See the Partnership Act, supra note 6, s 1(g); Re Thorne and New Brunswick Workmen's Compensation Board (1962), 33 DLR (2d) 167 at 168 (NBCA), aff'd [1962] SCR viii. 
accordance with the joint venturers' understanding, including with respect to any encumbrances on them.

The marketing of producing assets is also an important consideration with respect to joint ventures in the Canadian energy industry. Production from the assets belongs to the joint venture corporation or partnership or, with respect to a contractual joint venture, of each joint venturer as to its proportionate interest. Therefore, in certain cases the joint venture itself may market production. However, more often than not, the production is taken in kind by the joint venturers themselves through transfer at a market price and marketed by each joint venturer on its own behalf, or by the other joint venturer or a third party. ${ }^{59}$

\section{OTHER CONSIDERATIONS}

As the preceding discussion indicates, joint ventures are collaborative in nature. Although joint venturers themselves are separate entities, parties share decision making, assets, and the successes and failures of the joint venture. As a result, joint venturers should spend time and effort from the outset of their relationship ensuring they not only possess the right set of complementary skills, but also can work together. The joint venturers need to understand the business plans, objectives, capabilities, track record, and reputation of each other. Consideration also has to be given to whether a proposed joint venturer has the financial capability to carry out the joint venture and preliminary technical assessments should be done on operational integration, technology and relations, and any credit backstop that may be required in relation to that joint venturer. ${ }^{60}$ Often joint venturers do not find out they are not a good strategic fit or, worse, incompatible, until it is too late.

Cultural differences are also important to consider. In addition to the different legal regimes, various levels of reliance placed on lawyers and the different confidence in the legal system amongst joint venturers, joint venturers can often have very different negotiating styles and business environments depending on which part of the world they are from. Where joint venturers operate in parts of the world that are more challenging from the prospective of government involvement, such joint venturers may be impacted by such behaviours in their dealings in North America. Often difficulties encountered in other jurisdictions impact the behavior of joint venturers in the course of negotiations and affects the level of detail into which a joint venturer wants to get and the economics that a joint venturer is perceived as trying to extract from a transaction. The other joint venturers may view the level of detail as impractical. This leads to a heightened level of attention to detail on all sides, and to frustration. This is exacerbated by the fact that a joint venturer may be overly risk sensitive because the resources at stake are huge. This, in turn, may impact the level of control that such joint venturers want to exercise over the operation and management of the joint venture, resulting in potential redundancies and erosion of the value of the joint venture.

In addition to cultural differences, dealing with foreign investors may also create enforcement issues. To the extent a joint venturer does not have sufficient security through the assets of the joint venture alone, the joint venturer needs to consider how to protect its 
interest from defaults by other joint venturers. That joint venturer must understand the creditworthiness of the other joint venturers and any credit support providers. It must also understand the remedies available to it and the ability to enforce those remedies. Given the difficulty of enforcement against a foreign joint venturer's assets in certain jurisdictions, a joint venturer will want to ensure that it has access to sufficient resources of that joint venturer in Canada or other friendly jurisdictions.

\section{Concluding Thoughts}

Joint ventures can potentially have long durations, pose significant risks, and offer significant rewards to joint venturers. Joint ventures can help joint venturers achieve synergies that are not available to joint venturers on their own, assist joint venturers in managing their risk and deploying capital in a more efficient manner, reduce production times, and access efficient technologies that may otherwise take years for a joint venturer to develop on its own. However, joint ventures may also create increased administration costs for joint venturers and can cause joint venturers to lose control of certain assets and technology. If not structured properly, joint ventures can unduly restrict joint venturers and create liabilities on a joint venturer to which it would not otherwise be exposed. ${ }^{61}$ Therefore, an entity must carefully weigh the competing demands in the joint venture and attempt to align matters in such a way that joint venturers are incented to work together to achieve the specific goals of the joint venture. In that respect, joint venturers must pay keen attention to detail. Joint venturers can take the time to get things right from the beginning or spend much more time and resources in the future fixing complex issues that could have been avoided. ${ }^{62}$

Nathan Vanderklippe, “Oil patch goes to work on joint ventures,” The Globe and Mail (23 February 2012), online: GlobeAdvisor.com < https://secure.globeadvisor.com/servlet/ArticleNews/story/gam/ 20120223/RBENERGYJVS0223ATL $>$. 


\section{APPENDiX A \\ SUMMARY OF RECENT CANADIAN ENERGY JOINT VENTURES}

\begin{tabular}{|c|c|c|c|}
\hline Parties & Date & General Terms & Area \\
\hline $\begin{array}{l}\text { Encana } \\
\text { Corporation } \\
\text { and } \\
\text { Toyota Tsusho } \\
\text { Corporation }\end{array}$ & $\begin{array}{l}\text { Announced } 20 \\
\text { April } 2012^{63}\end{array}$ & $\begin{array}{l}\text { Toyota Tsusho to get a } 32.5 \text { percent interest for } \\
\$ 602 \text { million (consisting of } \$ 100 \text { million upfront } \\
\text { payment with commitment to invest remainder } \\
\text { within seven years) }\end{array}$ & $\begin{array}{l}\text { Horseshoe } \\
\text { Canyon in } \\
\text { southern } \\
\text { Alberta }\end{array}$ \\
\hline $\begin{array}{l}\text { Encana } \\
\text { Corporation } \\
\text { and } \\
\text { Mitsubishi } \\
\text { Corporation }\end{array}$ & $\begin{array}{l}\text { Announced } 17 \\
\text { February } 2012,{ }^{64} \\
\text { and closed } 24 \\
\text { February } 2012^{65}\end{array}$ & $\begin{array}{l}\text { Mitsubishi to pay } \$ 2.9 \text { billion for a } 40 \text { percent } \\
\text { interest ( } \$ 1.45 \text { billion on closing and } \$ 1.45 \text { billion } \\
\text { investment commitment) }\end{array}$ & Cutbank Ridge \\
\hline $\begin{array}{l}\text { Quicksilver } \\
\text { Resources Inc. } \\
\text { (by a subsidiary) } \\
\text { and } \\
\text { Kohlberg Kravis } \\
\text { Roberts \& Co. } \\
\text { (by a subsidiary) }\end{array}$ & $\begin{array}{l}23 \text { December } \\
2011^{66}\end{array}$ & $\begin{array}{l}\text { KKR to pay } \$ 125 \text { million plus commitment to carry } \\
\text { Quicksilver’s future development costs for } 50 \\
\text { percent stake and preferential distributions }\end{array}$ & $\begin{array}{l}\text { Horn River } \\
\text { Basin }\end{array}$ \\
\hline $\begin{array}{l}\text { Nexen Inc. } \\
\text { and } \\
\text { Consortium led } \\
\text { by Inpex } \\
\text { Corporation, } \\
\text { including JGC } \\
\text { Corporation }\end{array}$ & $\begin{array}{l}\text { Announced } 29 \\
\text { November } 2011 \\
\text { and expected to } \\
\text { close in the } \\
\text { second quarter of } \\
2012^{67}\end{array}$ & $\begin{array}{l}\text { Sale by Nexen of } 40 \text { percent interest for } \$ 700 \\
\text { million ( } 50 \text { percent up front and a } 50 \text { percent } \\
\text { capital carry) }\end{array}$ & $\begin{array}{l}\text { Horn River, } \\
\text { Cordova, and } \\
\text { Liard basins. }\end{array}$ \\
\hline
\end{tabular}

Encana Corporation, News Release, “Toyota Tsusho invests C\$600 million in Encana’s coalbed methane development in southern Alberta" (20 April 2012), online: Encana Corporation <http://files.shares holder.com/downloads/AMDA-I95FU/2060860699x0x5616334bc-edlc-4df5-93cf-7cc0156822c8/ ECA_News_2012_4_20_General_Releases.pdf>.

64 Encana Corporation, News Release, "Encana and Mitsubishi enter into partnership for development of Cutbank Ridge undeveloped lands in British Columbia” (17 February 2012), online: Encana Corporation <http://files.shareholder.com/downloads/AMDA-I95FU/2060860699x0x543452/e6165 fd8-c97b-41f9-82ae-390667a9194a/ECA_News_2012_2_17_General_Releases.pdf>.

65 Encana Corporation, News Release, "Encana and Mitsubishi complete partnership agreement for development of Cutbank Ridge undeveloped lands in B.C.” (24 February 2012), online: Encana Corporation <http://files.shareholder.com/downloads/AMDA-I95FU/2060860699x0x545531/24abbd 23-15a2-4387-b716-399c131f5671/ECA_News_2012_2_24_General_Releases.pdf>.

66 "Quicksilver Resources and KKR set up Horn River gas plant deal in BC," Canadian Business (27 December 2011), online: Canadian Business <http://www.canadianbusiness.com/article/63582- quick silver-resources-and-kkr-set-up-horn-river-gas-plant-deal-in-b-c>.

$67 \quad$ Nexen Inc, News Release, "Nexen Announces Sale and Joint Venture Partnership for Northeast British Columbia Shale Gas Assets” (29 November 2011), online: Nexen Inc <http://www.nexeninc.com/en/ AboutUs/MediaCentre/NewsReleases/News/Release.aspx?year=2011\&release_id=117759>. 


\begin{tabular}{|c|c|c|c|}
\hline Parties & Date & General Terms & Area \\
\hline $\begin{array}{l}\text { Progress Energy } \\
\text { Resources Corp. } \\
\text { and } \\
\text { PETRONAS } \\
\text { International } \\
\text { Corporation Ltd. }\end{array}$ & $\begin{array}{l}\text { Announced } 2 \\
\text { June } 2011^{68} \text { and } \\
\text { closed } 2 \text { August } \\
2011^{69}\end{array}$ & $\begin{array}{l}\text { Sale by Progress of a } 50 \text { percent interest for } \$ 1.07 \\
\text { billion ( } 25 \text { percent at closing and a } 75 \text { percent } \\
\text { capital carry) and agreement to pursue an LNG } \\
\text { export joint venture }\end{array}$ & $\begin{array}{l}\text { Altares, Lily, } \\
\text { and Kahta } \\
\text { properties in } \\
\text { North Montney }\end{array}$ \\
\hline $\begin{array}{l}\text { Talisman } \\
\text { Energy Inc. } \\
\text { and } \\
\text { Sasol Ltd. }\end{array}$ & $\begin{array}{l}\text { Announced } 8 \\
\text { March } 2011^{70} \text { and } \\
\text { closed } 10 \\
\text { June } 2011^{71}\end{array}$ & $\begin{array}{l}\text { Sasol to pay } \$ 1.034 \text { billion for a } 50 \text { percent share } \\
\text { (\$246 million in cash and remainder used to fund } \\
75 \text { percent of Talisman’s future capital } \\
\text { commitments) }\end{array}$ & $\begin{array}{l}\text { Cypress A } \\
\text { assets; Montney } \\
\text { shale play to be } \\
\text { integrated with } \\
\text { Farrell Creek }\end{array}$ \\
\hline $\begin{array}{l}\text { Talisman } \\
\text { Energy Inc. } \\
\text { and } \\
\text { Sasol Ltd. }\end{array}$ & $\begin{array}{l}\text { Announced } 20 \\
\text { December } 2010^{72} \\
\text { and closed } 1 \\
\text { March } 2011^{73}\end{array}$ & $\begin{array}{l}\text { Sasol to pay } \$ 1.05 \text { billion for } 50 \text { percent share } \\
\text { (\$260 million in cash and remainder used to fund } \\
75 \text { percent of Talisman’s future capital } \\
\text { commitments) }\end{array}$ & $\begin{array}{l}\text { Farrell Creek; } \\
\text { Montney shale } \\
\text { play }\end{array}$ \\
\hline $\begin{array}{l}\text { Suncor Energy } \\
\text { Inc. } \\
\text { and } \\
\text { Total E\&P } \\
\text { Canada }\end{array}$ & $\begin{array}{l}\text { Announced } 17 \\
\text { December } 2010^{74} \\
\text { and closed } 22 \\
\text { March } 2011^{75}\end{array}$ & $\begin{array}{l}\text { Suncor received } 36.75 \text { percent interest in Joslyn } \\
\text { and } \$ 1.75 \text { billion from Total in exchange for Total } \\
\text { receiving } 49 \text { percent in Voyageur upgrader and } \\
\text { interest in Fort Hills oil sands project }\end{array}$ & $\begin{array}{l}\text { Fort Hills and } \\
\text { Joslyn oil sands }\end{array}$ \\
\hline
\end{tabular}

Progress Energy Resources Corp, News Release, "Progress Energy Announces Strategic Partnership with PETRONAS to Develop Montney Shale Assets” (2 June 2011), online: Progress Energy Resources Corp <http://www.progressenergy.com/wp-content/uploads/2011/06/Progress-News-Release1.pdf> Progress Energy Resources Corp, News Release, "Progress Energy Announces the Closing of its Strategic Partnership with PETRONAS” (2 August 2011), online: Progress Energy Resources Corp <http://www.progressenergy.com/progress-energy-announces-the-closing-of-its-strategic-partnershipwith-petronas $>$.

Talisman Energy Inc, News Release, “Talisman Energy Deepens Its Strategic Partnership With Sasol in the Montney Shale Play” (8 March 2011), online: Talisman Energy <http://www.thepressreleasewire. com/client/talisman_energy/release.jsp?actionFor=1407464\&year=2011\&releaseSeq=1> ["TalismanSasol Strategic Partnership”].

$1 \quad$ Sasol Ltd, News Release, "Sasol Announces the Completion of the Second Acquisition of a 50\% Participation Interest in the Montney Gas Basin in Canada” (10 June 2011), online: Sasol Ltd <http:// www.sasol.com/sasol_internet/downloads/100611_Sasol_announces_completion_CypressA_ 1312532389292.pdf>.

Sasol Ltd, News Release, "Sasol signs CAD \$ 1050 / ZAR7 119 million agreement in Canada to significantly increase its contingent natural gas resources” (20 December 2010), online: Sasol Ltd <http://www.sasol.com/sasol_internet/frontend/navigation.jsp?navid=4\&rootid= 4\&articleId=29400001>.

See “Talisman-Sasol Strategic Partnership," supra note 70.

Total SA, News Release, “Total and Suncor form a strategic alliance in Canada's oil sands” (17 December 2010), online: Total < http://www.total.com/en/about-total/news/news-940500.html\&idActu= 2499>.

75 Suncor Energy, News Release, “Suncor Energy finalizes strategic alliance with Total E\&P Canada Ltd” (22 March 2011), online: Suncor <http://www.suncor.com/en/newsroom/2418.aspx?id=1415861>. 


\begin{tabular}{|c|c|c|c|}
\hline Parties & Date & General Terms & Area \\
\hline $\begin{array}{l}\text { Penn West } \\
\text { Petroleum Ltd. } \\
\text { and } \\
\text { Mitsubishi } \\
\text { Corporation (by } \\
\text { an affiliate) }\end{array}$ & $\begin{array}{l}\text { Announced } 24 \\
\text { August } 2010^{76} \\
\text { and closed } 23 \\
\text { September } 2010^{77}\end{array}$ & $\begin{array}{l}\text { Mitsubishi to pay approximately } \$ 850 \text { million for a } \\
50 \text { percent interest ( } \$ 250 \text { million at close and } \$ 600 \\
\text { million of future commitments) }\end{array}$ & $\begin{array}{l}\text { Shale and } \\
\text { conventional } \\
\text { natural gas } \\
\text { assets in the } \\
\text { Cordova } \\
\text { Embayment }\end{array}$ \\
\hline $\begin{array}{l}\text { Penn West } \\
\text { Petroleum Ltd. } \\
\text { and } \\
\text { China } \\
\text { Investment } \\
\text { Corporation (by } \\
\text { its subsidiary } \\
\text { Winter Spark } \\
\text { Resources, Inc.) }\end{array}$ & $\begin{array}{l}\text { Announced } 13 \\
\text { May } 2010^{78} \text { and } \\
\text { closed } 1 \text { June } \\
2010^{79}\end{array}$ & $\begin{array}{l}\text { CIC to receive } 45 \text { percent interest from Penn West } \\
\text { for approximately } \$ 1.3 \text { billion ( } \$ 312 \text { million at } \\
\text { close, a capital carry commitment of approximately } \\
\$ 505 \text { million, plus private placement financing } \\
\text { investment of } \$ 435 \text { million) }\end{array}$ & $\begin{array}{l}\text { Bitumen assets } \\
\text { in Peace River } \\
\text { area }\end{array}$ \\
\hline $\begin{array}{l}\text { Encana } \\
\text { Corporation } \\
\text { and } \\
\text { Korea Gas } \\
\text { Corporation (by } \\
\text { its subsidiary } \\
\text { Kogas Canada } \\
\text { Ltd.) }\end{array}$ & 1 March $2010^{80}$ & $\begin{array}{l}\text { Kogas to pay } \$ 1.1 \text { billion ( } \$ 565 \text { million for initial } 3 \\
\text { years) for a } 50 \text { percent stake in properties and } 20 \\
\text { percent interest in royalties }\end{array}$ & $\begin{array}{l}\text { Horn River and } \\
\text { Montney } \\
\text { formations }\end{array}$ \\
\hline
\end{tabular}

“Penn West Energy Trust Announces Strategic Joint Venture With Mitsubishi Corporation,” The Globe and Mail (24 August 2011), online: The Globe and Mail <http://www.theglobeandmail.com/globeinvestor/news-sources/?date=20100824\&archive $=$ ccnm\&slug=631016_1 $>$.

Penn West Energy Trust, News Release, "Penn West Energy Trust and Mitsubishi Corporation Announce Closing of Previously Announced Strategic Joint Venture” (23 September 2010), online: Marketwire <http://www.marketwire.com/press-release/penn-west-energy-trust-mitsubishi-corporationannounce-closing-previously-announced-tsx-pwt.un-1324384.htm>.

78 Penn West Energy Trust, News Release, "Penn West Energy Trust and China Investment Corporation Announce Strategic Partnership” (13 May 2010), online: Marketwire <http:/www.marketwire.com/ press-release/penn-west-energy-trust-china-investment-corporation-announce-strategic-partnershiptsx-pwt.un-1259607.htm>.

79 "Penn West Energy Trust and China Investment Corporation Announce Closing of Previously Announced Joint Venture and Equity Financing,” The Globe and Mail (1 June 2010), online: The Globe and Mail <http://www.theglobeandmail.com/globe-investor/news-sources/?date=20100601\&archive= ccnm\&slug=611858_1>.

80 "Korea Gas Corp expands investment in BC energy production,” The Globe and Mail (1 March 2010), online: The Globe and Mail <http://www.theglobeandmail.com/news/british-columbia/korea-gas-corpexpands-investment-in-bc-energy-production/article1365351/>. 


\begin{tabular}{|c|c|c|c|}
\hline Parties & Date & General Terms & Area \\
\hline $\begin{array}{l}\text { PetroChina } \\
\text { International } \\
\text { Investment Ltd. } \\
\text { and } \\
\text { Athabasca Oil } \\
\text { Corporation }\end{array}$ & $\begin{array}{l}\text { Announced } 31 \\
\text { August } 2009^{81} \\
\text { and approved } 29 \\
\text { December } 2009^{82} \\
\text { Option exercise } \\
\text { announced } 3 \\
\text { January } 2012^{83}\end{array}$ & $\begin{array}{l}\text { PetroChina paid } \$ 1.9 \text { billion for an initial } 60 \\
\text { percent interest in MacKay River and Dover and a } \\
\text { subsequent } \$ 680 \text { million for a } 100 \text { percent interest } \\
\text { in MacKay River }\end{array}$ & $\begin{array}{l}\text { MacKay River } \\
\text { and Dover oil } \\
\text { sands }\end{array}$ \\
\hline $\begin{array}{l}\text { BP plc } \\
\text { and } \\
\text { Husky Energy } \\
\text { Inc. }\end{array}$ & $\begin{array}{l}\text { Announced } 5 \\
\text { December } 2007^{84} \\
\text { and effective as of } \\
1 \text { January } 2008^{85}\end{array}$ & $\begin{array}{l}\text { Created two independent joint ventures through } \\
\text { exchange of } 50 \text { percent interest in Sunrise Field for } \\
50 \text { percent share in Toledo refinery under a US } \\
\text { refining LLC }\end{array}$ & $\begin{array}{l}\text { Sunrise Field in } \\
\text { Alberta; Toledo } \\
\text { oil refinery in } \\
\text { Ohio }\end{array}$ \\
\hline
\end{tabular}

81 Nathan Vanderklippe, "PetroChina buys 60\% stake in oil sands project,” The Globe and Mail (31 August 2009), online: The Globe and Mail <http://www.theglobeandmail.com/globe-investor/petro china-buys-60-stake-in-oil-sands-project/article4321586>.

82 "Ottawa Approves PetroChina Oil Sands Entry" (30 December 2009), online: Business Monitor International <http://store.businessmonitor.com/article/317079/>.

83 "PetroChina buys entire Alberta oilsands project," CBC News (3 January 2012), online: CBC News <http://www.cbc.ca/news/business/story/2012/01/03/athabasca-petrochina-mackay-oil.html>.

84 BP plc, News Release, “BP Enters Canadian Oil Sands with Husky Energy” (5 December 2007), online: BP plc <http://www.bp.com/genericarticle.do?categoryId=2012968\&contentId=7038865>. Ibid. 